\title{
The formation of ecosystems of employment for persons with disabilities
}

\author{
Tatyana Sokira ${ }^{1}$, Almazhan Dzhulaeva ${ }^{1}$, Zemfira Myshbayeva ${ }^{1, *}$, Saltanat Bolatkyzy ${ }^{2}$ and \\ Kenzhakhan Otepbergen ${ }^{1}$ \\ ${ }^{1}$ Al-Farabi Kazakh National University, Department of Management, al-Farabi Ave. 71, 050040 \\ Almaty, Kazakhstan \\ ${ }^{2}$ Almaty Technological University, Economic and management department, Tole bi str., 100, 050012 \\ Almaty, Kazakhstan
}

\begin{abstract}
The problem of employment of persons with disabilities is in the attention of all international organizations, is one of the seventeen sustainable development goals set by the UN, which defined decent work as an opportunity and prospects for personal development of any person, including those with disabilities. The urgency of this problem is becoming more acute in the modern world due to the fact that the number of disabled people is growing. This is due to the aging of the population - older people are at increased risk of disability, - and also because of the global increase in chronic diseases among the population. The article presents a comparative analysis of foreign and domestic experience in forming a social partnership ecosystem in solving the problems of persons with disabilities, analyzes the level of employment of persons with disabilities, and suggests practical steps for all stakeholders, including governments, civil society structures, and organizations of persons with disabilities, to create a favorable environmental ecosystem, develop rehabilitation and support services, and provide appropriate social support, developing inclusive policies and programs, and ensuring the application of new and existing standards and legislation for the benefit of persons with disabilities and the General public, based on a comparative analysis of the ecosystems of leading European States.
\end{abstract}

\section{Introduction}

Ensuring the sustainable development of mankind is the most significant problem facing the world community. "Sustainable development provides for meeting the needs of the present without compromising the ability of future generations to meet their needs." In July 2014, the UN General Assembly's working group on sustainable development goals identified a number of environmental, economic and social objectives aimed at achieving sustainable development that will end poverty, address inequality, and protect the planet from the harmful effects of production. One of the seventeen sustainable development goals calls for

\footnotetext{
*Corresponding author: zemfira.myshbayeva@mail.ru
} 
promoting sustainable, inclusive and continuous economic growth, full and productive employment, and decent work for all [1].

Decent work provides all people with income, self-development, and freedom of thought, equality to participate in decisions about their lives. This problem is particularly acute for people with disabilities. Today, it is important to understand disability as a priority issue in the field of development and human rights.

The purpose of this study is to determine the possibilities of creating an ecosystem for the social rehabilitation and sustainable development of persons with disabilities by providing them with employment based on a comparative analysis of the practice of social support and employment in developed countries of Europe and the EEU countries.

\section{Literature review}

Many authors are interested in the problem we are considering. They first of all agree that employment is important for people with disabilities and they represent a huge untapped potential of the labor force, as well as a virtually unused segment of the market [2]. At the same time, it is difficult for them to find work in the open labor market because of many barriers: environmental, individual and imitation. For example, Charette-Dussault, E., Corbière, $M$ think that environmental barriers include disability benefits, stigma, social support, and professional services [3]. Individual barriers, these same authors, are associated with illness, work experience and skills, as well as perception itself, fears, and motivation. The authors Piłat, A., Woźniak, B., Tobiasz-Adamczyk, B., Brzyska, M., Leonardi, M., Ferraina, S., Kadyrbayeva, A. also cite barriers to support itself, including problems with subsidies and professional integration services [4].

Group of authors Meltzer, A., Robinson, S., Fisher, K., Jonathon Breen., Farinaz Havaei and Cristina Pitassi believe that these barriers stem from a narrow, dismissive and discouraging attitude towards the work of disabled employers and discrimination in the workplace $[5,6]$. The attitude of employers makes a significant contribution to the successful employment of disabled people. As a result, people with disabilities refuse to work and use less inclusive work options. According to Miethlich, B, and Oldenburg, A needs to raise and improve regulatory requirements and funding to support people with disabilities, and professional counseling and training programs are needed to raise awareness among employers [2]. As a result, promoting employment for people with disabilities can help alleviate or even prevent future shortages of skilled workers.

A. Kantarbayeva believes that the promotion of the country's economy depends on entrepreneurs. Removing barriers and special measures to promote entrepreneurship must be implemented for the success of business development. For all social strata of the population, it is necessary to create centers of training and support for entrepreneurship. [7].

A large group of authors see the solution of employment problems for disabled people with the help of entrepreneurial ecosystems designed to ensure economic development and have the potential to solve social and economic problems in modern society for disabled people. Hazenberg, R., Bajwa-Patel, M., Mazzei, M., Roy, M., and Baglioni consider the emergence of four types of social entrepreneurship ecosystems such as macro and micro-public, macro and micro-private entrepreneurship [8]. Meanwhile, according to M. Glaser, B. Glaeser currently lacks an understanding of the social impacts of ecosystems on people and society, and therefore proposes to conceptualize the social dimension, emphasizing the role of social and environmental analysis, which is necessary for decision-makers and other practitioners. The same authors propose to distinguish between local and regional features of the social aspect of the relationship between man and nature in different institutional environments [9]. 
Of interest is the opinion of Roundy $\mathrm{P}$, who argues that entrepreneurial ecosystems influence the activities and effectiveness of social entrepreneurs through mechanisms such as: the diversity of resource providers, the availability of support infrastructure and entrepreneurial culture, as well as available training opportunities [10]. Social entrepreneurs can not only form entrepreneurial ecosystems, but also attract attention to the created ecosystem of interested parties, thereby increasing its profitability [11, 12].

Ivan Bozhikin, Janaina Macke, and Luana Folchinida Costa emphasize the role of government and non-state actors in social entrepreneurship, which are designed to influence the entire social entrepreneurship ecosystem using the tools available to them. These are: the combination and coordination of regulatory mechanisms to stimulate social entrepreneurship; public policy focused on the entire social entrepreneurship ecosystem; social capital; the availability of a business model for social entrepreneurship ecosystems and state support [13]. According to Spigel, it is the entrepreneurship ecosystem that enables professionals in the workplace to gain important policy knowledge on the development of fast-growing innovative enterprises and to form new ideas about the relationship between the phenomenon of entrepreneurship and the contexts of state programs [14].

At the same time, there are many barriers in the employment ecosystem. First of all, in the system of providing educational services to people with disabilities, as well as insufficient knowledge of employers on the skills and opportunities of people with disabilities, awareness of the degree of their disability, questions about hiring and retaining the system the provision of services $[15,16]$. These barriers restrict the access of persons with disabilities in the labor market are emphasized by Fisk, R., Dean, A., Alkire (néeNasr), L., Joubert, A., Previte, J., Robertson, N, and Rosenbaum, M [17]. They identify four key components of inclusion of persons with disabilities in society: enabling opportunities, choice, liberation from suffering, and promotion. All these components are interconnected and improve people's well-being.

Today, there are eight critical interventions for improving the situation of people with disabilities:

(1) Providing diagnostic services and family care at an early age;

(2) Providing technical training for specialists, employees, and teachers; and

(3) Providing technical training for teachers in specialized schools and inclusive schools;

(4) Equipping teachers in special and inclusive schools with specially designed training tools;

(5) Collaborating with corporations to create inclusive jobs;

(6) Implementing changes in legislation and training stakeholders, including parents and members of society, to raise awareness;

(7) Expanding the capacities of partner organizations and enabling them to create sustainable structures;

(8) Conducting research to collect data [18].

\section{Methods of research}

Achieving the goal and solving the tasks set in the study was carried out using methods of logical and comparative analysis, systematization, statistical analysis, evaluation and theoretical generalization.

\section{Results and Discussion}

The "Convention on the rights of persons with disabilities" by the UN General Assembly entered into force on may 3, 2008 after its ratification by twenty States members. To date, 
more than 150 countries and regional integration organizations have signed and 130 countries have ratified it. 10 countries of the Commonwealth of Independent States joined the Convention, including Kazakhstan (April 21, 2015). The Convention reflects a major shift in the global understanding of disability and responses to it.

Despite the adopted documents and initiatives, people with disabilities continue to face barriers to their participation in society as equal members, with violations of their human rights in all parts of the world. The employment rate of people with disabilities is $48.7 \%$, which remains much lower than the employment rate of people with disabilities (72.5\%) [19]. The international labor organization reports that nearly 400 million of the working - age population is disabled. Many of them do not work anywhere. Most employers consider them incapacitated. According to statistics, only $20 \%$ of the total numbers of people with disabilities are employed. The remaining $80 \%$ are unemployed.

In Europe, there are laws and rehabilitation programs aimed at eliminating discrimination against people with disabilities and helping them integrate painlessly into society. Every person needs employment, communication with people and equality of rights for their emotional and physical health. However, the employment rate of people with disabilities remains very low $-48.7 \%$. This confirms the relevance of the main goals of the European disability strategy for 2010-2020. The strategy aims to ensure that more people with disabilities earn a living in the open labor market.

Table 1. Comparative analysis of developed countries and the EEU countries by the number and employment of persons with disabilities.

\begin{tabular}{|c|c|c|c|c|c|c|c|c|}
\hline \multirow[t]{3}{*}{ Country } & \multicolumn{4}{|c|}{ Quantity } & \multicolumn{4}{|c|}{ Unemployment rate } \\
\hline & 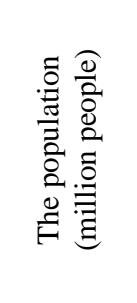 & 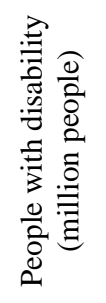 & 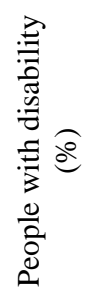 & 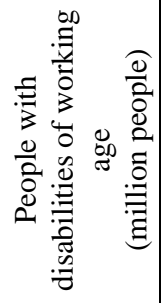 & 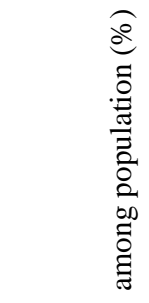 & & 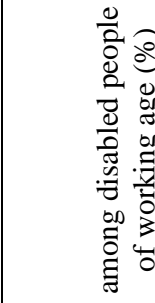 & \\
\hline & 2019 & 2019 & 2019 & 2019 & $2008-2012$ & 2019 & 2008-2012 & 2019 \\
\hline Germany & 83.2 & 7.8 & 9.3 & 3.3 & 11,1 & 3,1 & 14,5 & 9,2 \\
\hline France & 66.99 & 12.0 & 1.7 & 10 & 7,4 & 8,5 & 60 & 9,2 \\
\hline Italy & 57.00 & 2.60 & 4.5 & 0.52 & 10.7 & 9.8 & 6.9 & 8 \\
\hline Armenia & 2.9575 & 0.187 & 6.3 & 0.1158 & 14.7 & 18 & 90 & 92 \\
\hline Belarus & 9.50197 & 0.057 & 0.5 & 0.2 & 14 & 0.20 & 83 & 80 \\
\hline Kazakhstan & 18.91569 & 0.6802 & 3.5 & 0.4179 & 5.3 & 4.8 & 80 & 70 \\
\hline Russia & 146.7807 & 11.95 & 0.8 & 3.5 & 5,4 & 4.7 & 22,3 & 23,7 \\
\hline
\end{tabular}

As the analysis of the table shows, the number of people with disabilities is growing every year and in 2019 is: in Armenia -187,000 people (6.3\% of the population); in Belarus -571000 people( $6 \%$ of the population); in Kazakhstan -674200 people (3.6\% of the population); in Russia -11950000 people ( $0.8 \%$ of the population).

Comparison of data table. 1 shows that in developed European countries, the employment rate of persons with disabilities is significantly higher than in the EEU countries [20].

Today, the unemployment rate among people with disabilities of working age in the EEU countries remains ten times higher than in developed European countries. Moreover, over the past ten years, there has been a sharp decrease in the unemployment rate in European 
countries, while the situation in the EEU countries has not changed much, and demonstrates the stability of high barriers to employment for people with disabilities.

In the EEU countries, concrete steps have only recently been taken in the area of social protection and rehabilitation of disabled people. People with disabilities, although they consistently receive disability pension payments, are often isolated from society and left alone with their problem. In this regard, the EEU countries are actively working to create an ecosystem of entrepreneurship and employment for people with special needs.

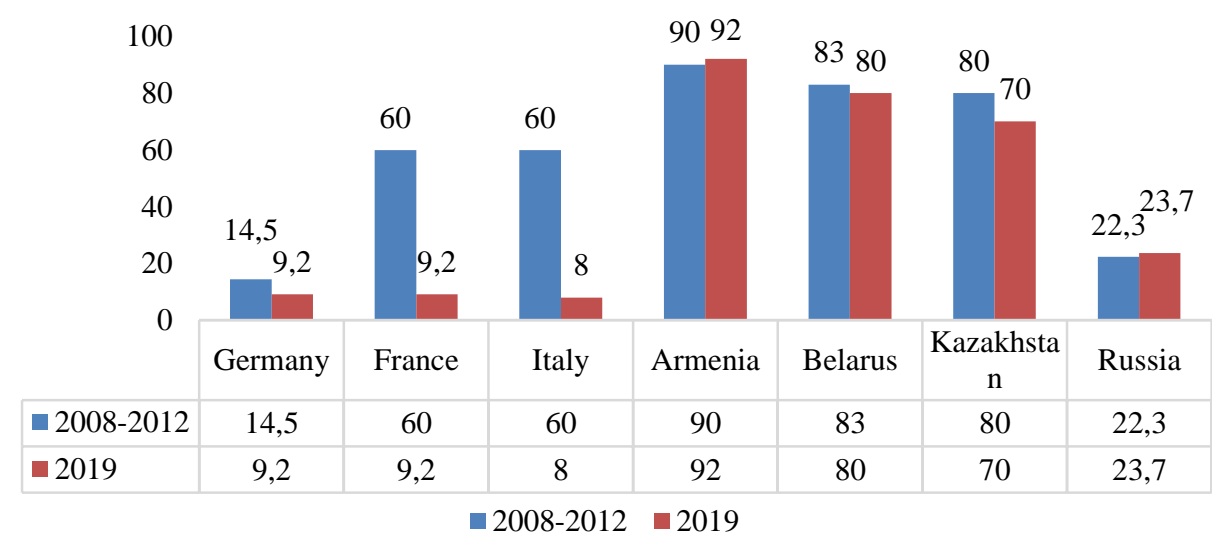

Fig. 1. Unemployment rate among persons with disabilities of working age in developed countries of Europe and in the EEU countries.

To solve the problems of employment of people with disabilities in the context of the sustainable development goals in Kazakhstan, it is necessary to analyze the practice of countries that have provided conditions for self-realization for people with disabilities by creating an ecosystem for people with disabilities.

The ecosystem represents a developed and purposeful level of relationships between the participants of a process that creates a synergistic effect. Thus, M. Peltoniemi and V. Vuori (2018), in their research on the innovation ecosystem, define the entrepreneurial ecosystem as a dynamic structure consisting of interconnected "populations" of organizations (small firms, corporations, universities, public sector organizations, etc.), within which there are processes of cooperation and competition at the same time [21].

M. Peltoniemi's research identified the following characteristics of the innovation ecosystem: self-organization;emergence;co-evolution; adaptability.

These properties are inherent not only in innovative ecosystems, but also in social spheres, which in the structure represent a network community, where participants have a high degree of self-organization and are characterized by a decentralized way of making decisions. Participants of the ecosystem for persons with disabilities are: the disabled themselves; state institutions and organizations that regulate the legal and financial aspects of their life support;state and private producers of material products, medical, educational, and cultural services for persons with disabilities; public, social, and volunteer organizations; and social services that form a social partnership or public-private partnership. In Table. 2 a comparative analysis of foreign and domestic experience in forming the social partnership ecosystem in the Federal Republic of Germany and the Republic of Kazakhstan is presented [22].

Analysis of the table data allows us to understand why in Germany the unemployment rate among people with disabilities of working age is $9.2 \%$, while in Kazakhstan it is $70 \%$. And it is not only that in European countries, processes aimed at ensuring the rights of persons 
with disabilities to self-realization began much earlier than in Kazakhstan. A key condition for the success of developed European countries in this area is the formation and development of an ecosystem for people with disabilities through social partnership between all participants in the social rehabilitation process.

Table 2. Model of an ecosystem of social partnership.

\begin{tabular}{|c|c|c|}
\hline \multicolumn{3}{|c|}{ Model methods and tools } \\
\hline Legal & Budget and financial & Social \\
\hline \multicolumn{3}{|c|}{ The Federal Republic of Germany } \\
\hline $\begin{array}{l}\text { Laws against discrimination } \\
\text { against persons with disabilities: } \\
\text { "on equalization of rehabilitation } \\
\text { services", "on social assistance". } \\
\text { They aimed at rehabilitation of } \\
\text { disabled people with the use of } \\
\text { insurance mechanisms, financing } \\
\text { the process of integration of the } \\
\text { disabled person into the working } \\
\text { life. The principle } \\
\text { "rehabilitation before retirement" } \\
\text { applies. The law on equality of } \\
\text { people with physical or mental } \\
\text { disabilities(2002) (Behinderteng- } \\
\text { leichstellungsgesetz) concerns the } \\
\text { work of departments at all levels } \\
\text { of the state, prescribes unhindered } \\
\text { access to public premises and } \\
\text { barrier-free access to information } \\
\text { and use of public transport. The } \\
\text { law on equal treatment (it. Das } \\
\text { Allgemeine Gleichbehand-lungs- } \\
\text { gesetz) - } 2006 \text { regulates relations } \\
\text { with the employer, access to } \\
\text { facilities and services in the } \\
\text { consumer and leisure sectors, } \\
\text { applies to the private sector of the } \\
\text { economy and protects against } \\
\text { discrimination. There are quotas } \\
\text { for jobs. The employment quota } \\
\text { for people with disabilities is } 4.67 \\
\% \text {, the goal is } 5 \% \text {. Businesses that } \\
\text { employ more than } 20 \text { people must } \\
\text { give at least } 5 \% \text { of their jobs to } \\
\text { people with disabilities. }\end{array}$ & $\begin{array}{l}\text { Firms that evade the } \\
\text { requirement to quota jobs } \\
\text { for people with } \\
\text { disabilities-pay a } \\
\text { monetary penalty for each } \\
\text { unoccupied rate. The } \\
\text { Federal employment } \\
\text { program provides various } \\
\text { benefits, grants and } \\
\text { subsidies to entrepreneurs } \\
\text { who employ disabled } \\
\text { people. There are more } \\
\text { than } 40 \text { specialties for free } \\
\text { training of disabled people } \\
\text { (from two months to two } \\
\text { years), including in trade, } \\
\text { processing of wood, } \\
\text { metal, leather and fabrics. }\end{array}$ & $\begin{array}{l}\text { "The code of social law", defines } \\
\text { the policy organization for the } \\
\text { disabled, guided by the principles: } \\
\text { providing all kinds of necessary } \\
\text { assistance to any disabled person } \\
\text { or person threatened by disability, } \\
\text { regardless of cause; integration of } \\
\text { the disabled into society; } \\
\text { intervention at the earliest stage, } \\
\text { when they should be taken all } \\
\text { measures for the reduction of } \\
\text { consequences of disability; } \\
\text { providing individual assistance } \\
\text { focused on the needs of a } \\
\text { particular disabled person. } \\
\text { Payments for persons who are not } \\
\text { able to work more than three } \\
\text { hours, receive a benefit-about } 9 \\
\text { thousand euros per year. Working } \\
\text { up to six hours-get half. The } \\
\text { principle works: the more work, } \\
\text { the less allowance. There is a } \\
\text { Federal employment program for } \\
\text { disabled people that provides } \\
\text { various benefits and subsidies to } \\
\text { employers of disabled people. The } \\
\text { state occupational accident } \\
\text { insurance Fund (DGUV) is } \\
\text { responsible for the distribution of } \\
\text { benefits and services: treatment, } \\
\text { rehabilitation, orthopedic devices } \\
\text { and their installations, care, and } \\
\text { benefits for participation in work. } \\
\text { A system of medical and } \\
\text { professional rehabilitation has } \\
\text { been established in } 11 \text { specialized } \\
\text { clinics to restore health and work } \\
\text { capacity. }\end{array}$ \\
\hline \multicolumn{3}{|c|}{ The Republic of Kazakhstan } \\
\hline $\begin{array}{l}\text { In accordance with the } \\
\text { Convention on the rights of } \\
\text { persons with disabilities, } 24 \\
\text { legislative acts have been } \\
\text { amended and supplemented, }\end{array}$ & $\begin{array}{l}\text { Since 2018, employers } \\
\text { have been subsidizing the } \\
\text { costs associated } \begin{array}{r}\text { with } \\
\text { equipping a } \quad \text { special } \\
\text { workplace }\end{array} \text { for }\end{array}$ & $\begin{array}{l}\text { Today, } 60 \%(4,207 \text { out of } 7,014) \\
\text { of secondary schools, } 20 \%(1,232 \\
\text { out of } 6,115) \text { of kindergartens, and } \\
58.8 \% \quad(70 \text { out of } 119) \text { of } \\
\text { universities } \quad \text { have } \quad \text { created }\end{array}$ \\
\hline
\end{tabular}


including 3 Codes on ensuring the accessibility of social and transport infrastructure and improving social services. The national plan for ensuring the rights and improving the quality of life of persons with disabilities in the Republic of Kazakhstan until 2025 has been adopted. The State program of health care development of the Republic of Kazakhstan "Densaulyk" for 2016 - 2019 has been completed. The quota for employment of persons with disabilities has been revisedfrom $2 \%$ to $4 \%$, depending on the number of employees and industry characteristics. As of January 1, 2019, 18.9 thousand people with a disability of $2.8 \%$ were included in the state program for the development of productive employment and mass entrepreneurship for 2017-2021 "Enbek".

\section{employment of persons with disabilities.} According to the Labour code, almost every company must have places for disabled people and employ them. Businesses that employ more than $51 \%$ of the disabled are exempt from VAT and social tax. The list of companies that set a quota for employment of disabled people - 3\% was approved. Administrative fines are provided for violations of the rights of persons with disabilities to work by officials and legal entities. There are 33 educational and production enterprises of the society for the blind and 18 for the deaf, where about 4,000 disabled people work on a permanent basis. A number of organizations assist in the employment and training of socially dependent groups. The Damu Foundation has launched a program to help disabled entrepreneurs. conditions for teaching and raising children with special needs. There are 247 railway stations, of which $91(37 \%)$ are in compliance with the requirements of the national standard of RK 1525-2013 for persons with disabilities. 18 functioning airports and $75 \%$ (27 out of 36) of bus stations meet the national standard. Special social services guaranteed by the state are provided to disabled people free of charge, and it is possible to choose the form of social services, up to and including home visits.Over the period from 2015 to 2018 , the number of recipients of services increased by $24.5 \%$, of which $46.1 \%$ were provided at home, $19.9 \%$. In stationary organizations. The number of organizations providing special social services has been increased to 893 units (797 - in 2015), of which home - based service organizations continue to hold the predominant positions-53\%, while stationary organizations accounted for $12.4 \%$. Since 2016, medical and social institutions have been transformed into social service centers. The participation of the non-governmental sector in the market for providing special social services under the state social order has increased from 4 in 2009 to 177 in 2018.

In Kazakhstan, this process is only at the initial stage. we need to create an effective mechanism for creating a system of ensuring the rights to self-realization of persons with disabilities, and above all, the right to work. Thus, in order to encourage employers to employ people with disabilities, since 2018, subsidies have been introduced for employers ' expenses related to equipping a special workplace for employment of people with disabilities. For these purposes, 105.6 million tenge was allocated from the national budget to create 770 special jobs. But this measure was implemented inefficiently on the ground. As a result, in the eight months of 2018 , only 88 jobs were created ( $11.4 \%$ of the plan) in the amount of 24.1 million tenge. Laws protecting the rights of disabled people in Kazakhstan, as in European countries, provide for quotas for jobs. There are also incentives for companies that comply with quotas, and penalties - fines for those who do not comply. However, the results are still far from necessary.

\section{Conclusion}


Despite the efforts made, employment and employment issues in Kazakhstan remain the most sensitive and topical for people with disabilities. The existing ecosystem needs to be improved. In Kazakhstan, as part of the new national plan to ensure the rights and improve the quality of life of persons with disabilities for 2020-2025, it is proposed to review the mechanisms for quotas and subsidies for employers ' costs for creating jobs. Meanwhile, it is obvious that in order to achieve the goals of sustainable development and ensure a decent life for people with disabilities in Kazakhstan, further changes are needed at the legislative level, in the practice of financing, the introduction of tangible tax benefits for employers, and in social aspects. In other words, it is necessary to develop all elements of the ecosystem for people with disabilities through the development of social partnership, based on the experience of European countries that have made significant progress in the employment of people with disabilities, creating harmonious and effective ecosystems.

\section{References}

1. Decent work for persons with disabilities: promoting rights in the global development agenda, 180 (ILO, Geneva, 2015)

2. B. Miethlich, A.G. Oldenburg, Proceed of the 33rd Intern. Bus. Inf. Manag. Ass. Conf., 7146-7158 (2019)

3. E. Charette-Dussault, M. Corbière, J. of Nerv. Ment. Dis, 207(7), 523-537 (2017)

4. A. Piłat, B. Woźniak, B. Tobiasz-Adamczyk, M. Brzyska, M Leonardi, S. Ferraina, A. Kadyrbaeva. Inter. J. Occupat. Med. Env. Health., 32 (4), 475-488 (2019)

5. A. Meltzer, S, Robinson, KR. Fisher. Soc. Policy. Admin., 54, 88-101 (2020)

6. J. Breen, H.Farinaz, C Pitassi, Disab. Rehab., 2135-2142 (2017)

7. A. Kantarbayeva, J.E Breaking, 1, 8 (2007)

8. R. Hazenberg, Bajwa-Patel, M. Mazzei, M. Roy, and S. Baglioni, Soc. Enterp. J., 3, 302-321 (2016)

9. M. Glaser, B. Glaeser. Treat. on Estuar. Coast S, Academ. P, 5-30 (2011)

10. P. Roundy, International Journal of Social Economics, 44(9), 1252-1267 (2017)

11. D. Nicholas, W. Mitchell, C. Dudley, J. Autism. Dev. Disord, 264-275 (2018)

12. S. Csillag, Z. Gyori, and C. Svastics, J. Enterp. Com: P. Plac in the Glob Econ., 13(1/2), 42-63 (2019)

13. I. Bozhikin, J. Macke, L. Folchini da Costa, J. Clean. Product, 226, 730-747 (2019)

14. B. Spigel, Emerald Publishing Limited, 20, 127-147 (2018)

15. A. Turginbayeva, G. Smagulova, L. Ashirbekova, R. Malikova, Proceedings of the 32nd International Business Information Management Association Conference, 3643-3647 (2018)

16. L. Shaw, L. Daraz, M. Bezzina, A. Patel, G. Gorfine, Emerald Group Publishing Limited, 185-210 (2014)

17. R. Fisk, A. Dean, L. Alkire, A. Joubert, J. Previte, N. Robertson, M. Rosenbaum, J. oService Manag, 29(5), 834-858 (2018)

18. A report Count me in. Building an inclusive ecosystem for persons with intellectual and developmental disabilities, bank of America (2018)

19. Convention on the rights of persons with disabilities (CRDP) (United Nations headquarters, New York, 2006)

20. B. Danemark, Academic Network of European Disability experts (ANED), 33-35 (2019)

21. M. Peltoniemy, V. Vuory, Business ecosystem as a new approach to complex adaptive business environments (2008) 
22. Akhmetshin, E. M., Vasilev, V. L., Vlasova, N. I., Kazakov, A. V., Kotova, X. Y., Ilyasov, R. H. Quality - Access to Success, 20(171), 39-43. (2019). 